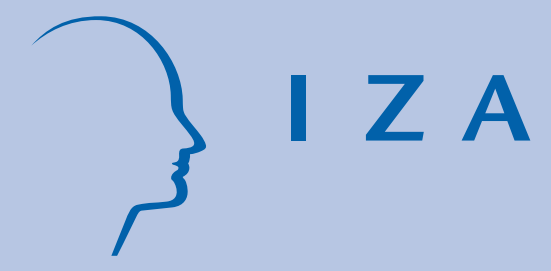

IZA Policy Paper No. 4

How to Avoid a Pension Crisis:

A Question of Intelligent System Design

Alessandro Cigno

April 2009 


\title{
How to Avoid a Pension Crisis: A Question of Intelligent System Design
}

\author{
Alessandro Cigno \\ University of Florence, CESifo, CHILD \\ and IZA
}

Policy Paper No. 4

April 2009

IZA

P.O. Box 7240

53072 Bonn

Germany

Phone: +49-228-3894-0

Fax: +49-228-3894-180

E-mail: iza@iza.org

The IZA Policy Paper Series publishes work by IZA staff and network members with immediate relevance for policymakers. Any opinions and views on policy expressed are those of the author(s) and not necessarily those of IZA.

The papers often represent preliminary work and are circulated to encourage discussion. Citation of such a paper should account for its provisional character. A revised version may be available directly from the corresponding author. 
IZA Policy Paper No. 4

April 2009

\section{ABSTRACT \\ How to Avoid a Pension Crisis: A Question of Intelligent System Design*}

Conventional pension systems suffer from a design defect which makes them financially unsustainable, and a source of inefficiency for the economy as a whole. The paper outlines a second-best policy which includes a public pension system made up of two parallel schemes, a Bismarckian one allowing individuals to qualify for a pension by working and paying contributions in the usual way, and an unconventional one allowing them to qualify for a pension by having children, and investing time and money in their upbringing.

JEL Classification: D13, D64, H55, J13, J14, J26

Keywords: pension reform, implicit pension taxes and subsidies, child benefits, fertility, labour productivity

Corresponding author:

Alessandro Cigno

Università di Firenze

Dipartimento di Studi sullo Stato

Via S. Caterina d'Alessandria 3

50129 Firenze

Italia

E-mail: cigno@unifi.it 


\section{Introduction}

Fertility has fallen throughout what is now the industrialized world for the last two and a half centuries. $^{2}$ In relative terms, however, the fall has been more pronounced since the end of the second world war. After a temporary recovery in the 1960s, the total fertility rate (TFR) declined for almost two decades before settling below the replacement level of 2.1 births per woman everywhere, and well below that level in Japan and much of continental Europe. In those two decades, public pension systems reached also their maximum expansion. Is that coincidence? The data show a negative correlation over time and across countries between the TFR and the share of pension or, more generally, social expenditure in GDP. ${ }^{3}$ Correlation does not necessarily imply causation. There appears to be a consensus, however, that public, especially pension, expenditure has risen partly because fertility has fallen.

The consensus argument runs roughly as follows. For any given level of life expectancy at birth, and any given age of retirement, a reduction in the fertility rate gives rise, in due course, to an increase in the dependency ratio. Where, as in much of the industrialized world, the state has taken over from the family as the main source of old-age support, any increase in the dependency ratio translates into a larger share of pension benefits, and health and social facilities for the aged, in public expenditure, not only because more persons qualify for public transfers and services under the existing rules, but also because the rules change in favour of the old as a consequence of their increased electoral weight. ${ }^{4}$ These effects are stronger if, as it has been the case, life expectancy rises too, but the statutory age of retirement (or the one at which a person starts to draw a pension) does not rise as fast, because of opposition by those political parties and trade unions which predominantly represent the older segment of the electorate. Where pensions are concerned, these adverse effects are exacerbated if fertility reductions, and increases in life expectancy, are accompanied by a slowdown in productivity growth (as in Europe since the 1970s). As public pension systems are all essentially pay-as-you-go, their implicit rate of return is in fact equal to the growth rate of aggregate earnings, and thus an increasing function of the growth rates of both the labour force, and labour productivity. The conventional response to this consensus argument is to raise contributions and reduce benefits (in various ways, including raising the age at which a person can start drawing a pension). ${ }^{5}$

\footnotetext{
${ }^{2}$ See Mitchell (2003).

${ }^{3}$ See, for example, Puhakka and Viren (2006).

${ }^{4}$ For a survey of the relevant political economy literature, see Cigno (2006b).

${ }^{5}$ A detailed proposal for reforming the US public pension system along these lines is in Diamond and Orszag (2005). Using generational accounting, however, Kotlikoff and Burns (2004) show that the pension crisis awaiting the US is much worse than it appears if one just looks at current account balances, and that this crisis is unlikely to be avoided by fiddling with benefit and contribution rates (so much so, that they advice US citizens to differentiate their private portfolios outside the US).
} 
In the present paper, I review evidence that causation may indeed run from population and productivity to pension expenditure in the short run. In the long run, however, causation runs the opposite way. The existing public pension schemes, all essentially pay-as-you-go, tend to eat away at their own tax base. But that is not inevitable. I argue that a pension system can be redesigned so that couples and individuals will (a) exploit their comparative advantages in the production of present (their own) or future (their children's) earning capacity, and (b) internalize the benefits of producing the latter. I further argue that the proposed reform is desirable not only because it makes the pension system financially viable, but also because a pension system thus designed is a valuable policy instrument in its own right. Section 2 summarizes the underlying theory. Section 3 examines the evidence. Section 4 outlines the second-best policy. ${ }^{6}$ Section 5 puts forward a specific proposal, and discusses a simulation of the effects of the proposed reform vis-a-vis those of more conventional policies.

\section{Public pension provision and private reproductive behaviour}

A conventional pension scheme levies contributions on each working-age individual, and pays each retirement-age individual benefits which are independent of whether or how many children this person has, and how much they are or will be paying in taxes and pension contributions. Individual contributions are an increasing function of individual incomes. Individual benefits are independent of individual contributions if the scheme is Beveridgean, increasing in them if it is Bismarckian. If, at the time of retirement, the expected value of the benefits is equal to the capitalized value of the contributions, we say that the scheme is actuarially fair. A Bismarckian scheme can be designed to be actuarially fair to all participants, a Beveridgean scheme can be so to only one or a few (typically to those in the middle of the earnings distribution). If the expected benefits are higher than the capitalized contributions at the time of retirement, the agent is getting an implicit subsidy. If they are lower, he is paying an implicit tax. ${ }^{7}$ How does compulsory participation in a pension scheme affect behaviour?

Let us start with the labour effects. ${ }^{8}$ If the scheme is Beveridgean, the pension contribution is an income tax in all but name because it does not translate into higher benefits for the person who pays it, and will thus discourage labour. The argument is not so straightforward if the scheme is Bismarckian. If the scheme is actuarially fair for a particular agent, the pension contribution made by this person is not a tax but a form of saving. Provided that the agent is not credit rationed, therefore, it will not affect his labour decisions. If the scheme is not actuarially fair, by contrast, the

\footnotetext{
${ }^{6}$ The technical reader is referred to the journal articles on which this one draws.

${ }^{7}$ The concept of an implicit pension tax comes from Sinn (1990).

${ }^{8}$ The analysis that follows is based on Cigno (2008).
} 
implicit pension tax (subsidy) will induce the agent to supply less (more) labour. If it is designed to redistribute from rich to poor pensioners, ${ }^{9}$ high-wage earners (who pay an implicit tax) will work less, and low-wage earners (who receive an implicit subsidy) will work more. The aggregate labour effect is thus likely to be small, and may even be positive. ${ }^{10}$ In the presence of credit rationing, there is a further effect. As a euro today is worth for a credit-rationed agent more than the capitalized value of a euro tomorrow, the policy will in fact reduce this person's marginal return to work. This further effect will reinforce the negative one of any implicit pension tax the agent may be paying, but will tend to offset the positive effect of any implicit pension subsidy he may be receiving.

Let us now look at fertility and transfers effects. Suppose that people derive direct utility not only from their own lifetime consumption, but also from the number ("quantity”) and lifetime utility ("quality") of their children as in Becker and Barro (1988). Consider the effects of introducing an actuarially fair Bismarckian pension scheme in such a model. ${ }^{11}$ In the absence of credit rationing, the only effect would be to reduce voluntary saving by the amount of the pension contribution, because the agent's wealth position would not be affected by the policy. Labour, fertility, and transfers to children would not be affected. In the presence of credit rationing, however, and assuming that future consumption, and the quantity and quality of children are normal goods, the policy would cause voluntary saving to fall by more than the amount of the pension contribution because it would tighten the borrowing constraint; fertility and voluntary transfers to each child would fall too. What if the scheme is not actuarially fair?

Suppose that agents are promised an implicit pension subsidy. If the burden of paying for the subsidy were to fall on each agent's own children (in the form of lower benefits, or higher taxes and contributions), this person would altruistically pass the subsidy on to her children in the form of higher bequests, or higher inter-vivos transfers. The agent's fertility plan would not be affected because, after the additional voluntary transfer, her lifetime wealth is the same as without the pension subsidy. In a conventional pension scheme, however, the burden of paying for the subsidy falls on everybody's children, not just on those of the person who receives the subsidy. This gives rise to a free-riding problem, as each agent will try to shift the burden on to other people's children by having fewer of her own, and more than compensating each of her own children for their share of the burden. The effects of an implicit pension subsidy will then be a reduction in the fertility rate, and an increase in the amount transferred, on average, to each child. The effects of an implicit

\footnotetext{
${ }^{9}$ A Beveridgean scheme is redistributive by its very nature, but a Bismarckian one need not be.

${ }^{10}$ Cigno (2008) shows that a Bismarckian scheme will always discourage labour less than a Beveridgean one of the same size.

${ }^{11}$ These effects are not considered in Becker and Barro (1988), where it is implicitly assumed that the pension scheme is Beveridgean. The analysis that follows draws on Cigno and Werding (2007).
} 
pension tax are the opposite. It would thus seem that pension policy can affect fertility only if the scheme is not actuarially fair, or the credit market is imperfect.

The foregoing analysis implies that individual decisions are restricted only by the law of the land. But there is ample descriptive evidence (and some econometric results to be reported later) that family norms also play a role. Cigno (2006a) shows that an unwritten "family constitution" prescribing the minimum amount of money (or personal services yielding the same utility) a working-age person must give each of her young children, if she has any, and her retirement-age parents, if they obeyed the rules, may be self-enforcing not only in the sense that it is not in any adult's interest to disobey the rules (Nash equilibrium), but also in the stronger sense that it is not in any generation's interest to change the rules (renegotiation-proofness). ${ }^{12}$

Compulsory participation in an actuarially fair pension scheme makes it less advantageous for a working-age individual to abide by a family constitution because part or all of this person's demand for old-age consumption is now met by the pension. ${ }^{13}$ If the policy in question is enacted, a number of family constitutions will then cease to be self-enforcing, and the aggregate fertility rate will consequently fall. The effect on the amount transferred, on average, to each child is ambiguous. ${ }^{14}$ In the presence of self-enforcing family constitutions, the policy will thus reduce fertility, and may raise the amount of parental transfers received on average by each child. If the pension scheme is not actuarially fair, there will be additional effects. ${ }^{15}$ Any implicit pension subsidy makes it more likely that a self-enforcing constitution exists, but will also induce parents to substitute quantity for quality of children. Therefore, it will strengthen the fertility effect, but may weaken the effect on parental transfers. Any implicit pension tax will do the opposite.

Finally, let us look at the effects of the instrument that policy makers instinctly reach for in a phase of below-replacement fertility, namely cash benefits or tax breaks for parents with young children. As it reduces the marginal cost of quantity relative to that of quality, a fertility subsidy induces parents to substitute the former for the latter. The policy results therefore in a larger number of poor children. ${ }^{16}$ If the subsidy is financed by a general income tax, this will discourage labour.

\footnotetext{
${ }^{12}$ May rather than will, because working-age individuals have the alternative of disobeying the rules, give nothing to their parents, and provide for their own old age by saving. A necessary but not sufficient condition for a constitution to be self-enforcing is that the marginal return to money spent on children is sufficiently higher than the market return to conventional investments, to compensate for the fixed cost of supporting the agent's own parents at the prescribed level. 13 See again Cigno (2006a).

${ }^{14}$ Some parents (those who, without the policy, would have given their children more than the minimum prescribed by their family constitution) will in fact compensate for the reduction in quantity by raising the quality of children. Others (those who, without the policy, would have given their children the minimum prescribed by their family constitution but, with the policy, will disobey the constitution) will make smaller voluntary transfers to each child they may decide to have.

${ }^{15}$ See Cigno et al. (2003a).

${ }^{16}$ Cigno (1986) appears to have been the first to point this out.
} 


\section{Some evidence}

Consistently with the proposition that money paid into a Bismarckian pension scheme is, at least in part, a form of saving rather than a tax on labour, and that an implicit pension subsidy (tax) is an incentive (a disincentive) to work, Disney (2004) finds cross-country evidence that labour participation is either unaffected, or positively affected, by the estimated saving component of pension contributions. Descriptive evidence of transfers from grown-up children to elderly parents is found in a great number of data sets regarding not only developing coutries, but also highly developed ones like Western Europe and the US (where they take predominantly the form of personal services, rather than cash). Econometric evidence that a statistically significant fraction of the working-age population behaves in a way which is consistent with the existence of a family constitution is found by Cigno et al. (2006b) in Italian survey data. The prediction that, in the presence of self-enforcing family constitutions, the introduction or expansion of a public pension scheme will always reduce fertility is corroborated by a substantial number of empirical studies. Evidence of an effect on parental transfers per child is more limited.

Early studies like Entwisle and Winegarden (1984), Hohm (1975), and Nugent and Gillaspy (1983), report cross-country evidence that public pension provision discourages fertility. More recent investigations allow for saving, fertility and, in some cases, educational investment and productivity growth to be jointly determined. Single-country, time-series studies like Cigno and Rosati (1992, 1996), and Cigno et al. (2003a), find that pension coverage has a negative effect on fertility, and a nonnegative one on household saving. Cross-country studies like Ehrlich and Zhong (1998), and Zhang and Zhang (2004), also find that pension coverage has a negative effect on fertility; but the first of these papers estimates a negative effect on both saving and productivity growth, while the second estimates a zero effect on saving, and positive effects on both educational investment and productivity growth.

In cross-country investigations, pension policy is usually represented by the share of pension payments in GDP. Data limitations do not permit to do otherwise. In time-series analyses, by contrast, it is possible to distinguish between two dimensions of pension policy. One consists in extending pension coverage to a larger share of the population without any change in the wealth position of the individuals covered (i.e., what would happen if the pension scheme were actuarially fair). The other changes the wealth position of the individuals covered by introducing or changing the level of implicit pension subsidies or taxes. In the studies for which I am responsible, the second dimension is measured as the difference between benefits paid out, and contributions cashed in, by the pension system in the accounting year (in the long run, this difference tends to coincide with the implicit generational subsidy). As already reported, the first dimension of pension policy is 
estimated to have a negative effect on fertility, and a nonnegative one on household saving. The second has positive effects on both fertility, and household saving. Therefore, a pension subsidy (tax) weakens (strengthens) the fertility, and strengthens (weakens) the saving effect of public pension provision.

Cigno et al. (2003a) use a VAR model, which does not assume the direction of causation a priori like the earlier studies, but leaves this to be determined by the data, and allows also for all possible cross-effects. The model controls for male and female after-tax wage rates, the real interest rate and child benefits, and takes also account of the introduction of the contraceptive pill in the 1960s. The estimates show that causation runs from pension policy to saving and fertility behaviour in the long run, but also that there may be reverse causation in the short run. Consistently with the hypothesis that fertility is the outcome of voluntary actions, the estimates also show that the contraceptive pill has made fertility more responsive to policy. The finding that fertility and saving respond to implicit pension taxes and subsidies explains the contradictory estimates of the saving, and productivity growth, effects estimated, without controlling for such taxes and subsidies, by Ehrlich and Zhong (1998) on the one hand, and Zhang and Zhang (2004) on the other.

We now come to child benefits. These have long been the subject of econometric investigation, and the finding is invariably that fertility-related cash benefits or tax breaks encourage fertility. But the effect usually estimated is short term -- essentially a change in the tempo of fertilty (like the one wihich gave rise to a baby boom in the 1960s) rather than a change in completed cohort fertility. Consistently with our theoretical considerations, the long-term effect appears to be substantially smaller. ${ }^{17}$ For Germany, Cigno et al. (2003a) estimate a long-run elasticity of the TFR to the child benefit rate of only 0.23 . This means that doubling an already generous package of fertility-related cash benefits and tax breaks would eventually raise completed fertility by little over a quarter of a child per woman.

\section{Why public pensions?}

Given that a family governed by a self-enforcing set of rules acts as a kind of informal welfare system, and that some of these family-based systems will be displaced by the introduction of a public pension system, ${ }^{18}$ the question naturally arises "why have a public pension system at all”. The conventional answer is threefold. First, an informal family transfer system may be inefficient. Unlike paying taxes and pension contributions, working-age individuals are not in fact obliged to

\footnotetext{
${ }^{17}$ See the survey in Schultz (2007).

${ }^{18}$ Given that a pension system provides a pensioner with money, but not with the personal services of the pensioner's own children, and given that the market does not offer perfect substitutes for such services, family constitutions are unlikely to disappear altogether. The evidence suggests that intra-family transfer systems survive between the folds of even the most extensive pension and welfare systems; see Cigno (2006a) and (2006b).
} 
comply with a family constitution. They must be given an incentive to do so. If this participation constraint is binding, ${ }^{19}$ the implicit return offered by the family scheme may be higher than the interest rate. ${ }^{20}$ Second, a nation-wide pension system may be used to redistribute across families. In particular, it allows the government to provide for the old and destitute. To this it might be objected that the same aim could be pursued, at lower cost, by directly subsidizing those whose retirement income falls below a certain level. But there is a moral hazard problem. Knowing of this meanstested subsidy, low-wage earners would in fact have no incentive to save (as their savings would be effectively taxed away by the loss of subsidy). Third, risks are less likely to be positively correlated across families, than across members of the same family. Therefore, a redistributive pension system offers better insurance than a family ever could.

There are thus arguments in favour of a public pension system. But are there arguments in favour of a pay-as-you-go one? The answer is no. In such a system, a birth brings benefits to all currently working-age individuals, because there will be an extra person to pay contributions when they retire. The same is true of each euro, and each minute of their own time, that the parents spend on a child. But there is no way and no reason for an individual or a couple to take account of these external effects in deciding whether to have an extra child, and how much to invest in the new born. Conditionally on the existence of a pay-as-you-go pension system, the agent will then have fewer children, and invest less resources in each of them, than would be efficient. The size of this externality could be very large. ${ }^{21}$ It would be smaller if the pension system were fully funded (because it would then arise only from the government's attempts to insure and redistribute), but this is not a good reason for switching from pay-as-you-go to full funding, because the cost of funding the pensions of the transition generation, whose contributions served to pay benefits to the previous one, would never be recovered. ${ }^{22}$

Given that a pay-as-you-go pension scheme is in place, a switch to full funding would consequently reduce welfare. Indeed, a fully-funded pension system would not be socially optimal even if we were starting from scratch. Starting from the premise that the government observes the number of children, but not (or not perfectly) the amount of money and personal attention that parents spend on each of them, Cigno et al. (2003b) demonstrate that the second-best policy makes use of (i) a subsidy increasing in number of children, and (ii) a subsidy increasing in the future earning capacity of these children. Of these instruments, (i) may be interpreted as a combination of

\footnotetext{
${ }^{19}$ Whether it is or not depends on how rich and altruistic the agent is, and on the level of the market interest rate; see Cigno (2006a).

${ }^{20}$ Will be higher if individuals are not altruistically motivated; see Cigno (2006a).

${ }^{21}$ Werding and Hofmann (2005) calculate that the benefit of an extra birth for the German pension system is, on average, about 139000 euros in present value terms.

${ }^{22}$ See Breyer (1989), Fenge (1995) and Sinn (2000).
} 
child benefits and educational subsidies, and (ii) as either a scholarship or an unconventional pension benefit. The intuitive explanation of why (ii) is needed is that, as already noted, (i) on its own would induce parents to substitute quantity for quality of children. The only difference between the two possible interpretations of (ii) lies in the fact that the first requires the child's earning potential to be assessed at a much earlier stage, and thus on the basis of much more limited information, than the second. I shall concentrate on the latter.

A person's lifetime earning potential depends on luck, as well as on the amount of time and money that this person's parents have invested in his or her formal and informal education. This has two implications. The first is that the policy maker cannot infer the amount of investment carried out by the parents from the child's earning capacity, and cannot thus order parents to (threaten them with a penalty if they do not) invest at the efficient level. It can only give them the incentive to do so by promising them a reward (the pension benefit) which increases with their children's ability to pay taxes and contributions. The second is that the investment is risky (a child may turn out dull or delinquent). Without the policy, and assuming risk aversion, parents would consequently invest less than the efficient amount. The second-best pension benefit will then include both an incentive and an insurance element (but not full insurance, because that would blunt the incentive to invest). Cigno et al. (2004) introduce a further consideration. Allowing for working-age individuals to differ in their relative ability to make money or raise children, they show that (a) the second-best number of children differs across couples and individuals, and (b) the policy is designed to encourage those with a comparative advantage in raising children to work less, and have more children, than those with a comparative advantage in raising money.

\section{A proposal for pension reform, and some simulations}

A way to make the theoretical results in Cigno et al. (2003b, 2004) operational is to have a pension system made up of two parallel schemes,

(i) a conventional Bismarck-type one allowing the agent to earn a pension by working and paying contributions in the usual way, and

(ii) an unconventional children-related one allowing the agent to earn a pension by raising children, and investing in their human capital.

In (i), individual benefits would increase with individual earnings and contributions. In (ii), they would increase with the earnings potential of the pensioner's own children, estimated on the basis of observable parameters such as education achievement, and actual labour market performance, ${ }^{23}$ up to the time when the parent retires. Recalling that a second-best policy is a compromise between

\footnotetext{
${ }^{23}$ These are the personal charateristics routinely used by labour econometricians to predict a person's earnings potential.
} 
incentive and insurance considerations, the benefit formulae should be designed to partially compensate the pensioner if his own lifetime earnings turn out to have been unsatisfactory in scheme (i), or if his children's estimated earnings capacity turns out to be unsatisfactory in scheme (ii). ${ }^{24}$

Individuals should be free to switch in and out of the two schemes as and when they like. Those who, by chance or choice, remain childless would obviously stay in scheme (i) throughout their working lives. This freedom of choice would encourage couples and individuals to specialize in either child-raising or money-raising activities according to their personal comparative advantages; notice that the government would not need to know these comparative advantages, it is sufficient that individuals do. ${ }^{25}$ It would also minimize labour distortion, because (ii) does not tax labour, and (i) taxes or subsidizes it only for the amount of time that a person allocates to this scheme. In the absence of credit rationing, any such distortion could be eliminated altogether by designing (i) to be actuarially fair to every participant (see Section 2). That, however, would not allow redistribution from rich to poor pensioners, and is thus unlikely to be a feature of second-best policy.

A small element of what is being proposed exists already in some pension systems. The majoration de durée d'assurance pour enfants in the French Régime Général, and the Swedish extrapension för barn, are pension-based fertility subsidies. As such, they encourage fertility, but trigger a negative substitution-effect on child quality. Something resembling (ii) was introduced in Germany in 1986, when the government started crediting parents who withdrew from the labour market to look after a child with a notional pension contribution, Kindererziehungszeiten. As this reflected, however imperfectly, the opportunity-cost component of the cost of having a child, the policy went some way towards providing an incentive not just to have children, but also to spend time with them. Since 1996, however, the condition that the parent should actually give up work in order to qualify for the benefit has been removed, and Kindererziehungszeiten has become a pension-based fertility subsidy just like the French and Swedish ones.

Cigno and Werding (2007) simulate the effects of the pension reform proposed here, and of more conventional policies, using the already mentioned econometric model of West Germany in Cigno et al. (2003a). This model was estimated using aggregate data for the 1960-95 period, the longest for which the relevant information will ever be available. The simulations cover the 19962020 period. The model predicts both long and short term adjustments. As the direction of causation

\footnotetext{
${ }^{24}$ One may have a dull or delinquent child, but may be also disappointed in one's own career expectations.

${ }^{25}$ Fenge and Meier (2005) derive the actual weights that should be given to children and pension contributions in the calculation of pension benefits. But they do this under the assumptions that all individuals are the same, and thus that there are no comparative advantages.
} 
is from policy to individual behaviour in the long run, but from individual behaviour to policy in the short run (see Section 3), the simulations concern only the long-run adjustments (in other words, they show would have happened between 1996 and the time of writing, and would happen from then on, if individuals adjusted instantly to policy changes). The dependent variables are fertility and household saving. The policy variables are pension coverage, the implicit pension subsidy, and the child benefit rate. The control variables include the real after-tax male and female wage rates, the real interest rate, and the availability of modern contraception.

Pension coverage is measured as the ratio of pension payments at constant prices to the number of persons aged 65 (the statutory age of retirement) or over. Variations in this ratio reflect changes in longevity, in the effective age of retirement, in the level of the pension benefit in the first year after retirement, and in the method used to uprate this benefit in subsequent years. The implicit pension subsidy is measured as the difference between current pension benefits and current pension contributions (i.e., as the deficit of the pension fund current account), expressed as a percentage of the latter. The child benefit rate is the per-child sum of all the fertility-related cash payments (including Kindererziehungszeiten) and tax allowances, again at constant prices.

Figure 1, reproduced from Cigno and Werding (2007), shows what would have happened to TFR between 1995 and the time of writing, and would happen between that date and 2020, in five of the alternative policy scenarios considered in that book (the labels attached to these scenarios are those used by the original authors).

S1. Pension coverage grows, on average, at the same rate (2\% a year) as over the estimation period. The implicit pension subsidy and the child benefit rate are held constant at their 1995 level. This is an extrapolation of the 1995 status quo.

S6. Pension coverage declines by $2 \%$ a year. The implicit pension subsidy is held constant, in real terms, at the 1995 level. The child benefit rate increases in real terms by $1.2 \%$ a year from its 1995 level. This scenario involves a radical shift of resources from old-age support to fertility incentives.

APS. Pension coverage is the actual one until 2001, and the one implied by the 2001 pension reform from then on. The implicit pension subsidy is held constant, and the child benefit rate increases by $1.2 \%$ a year, as in $\mathbf{S 6}$. 


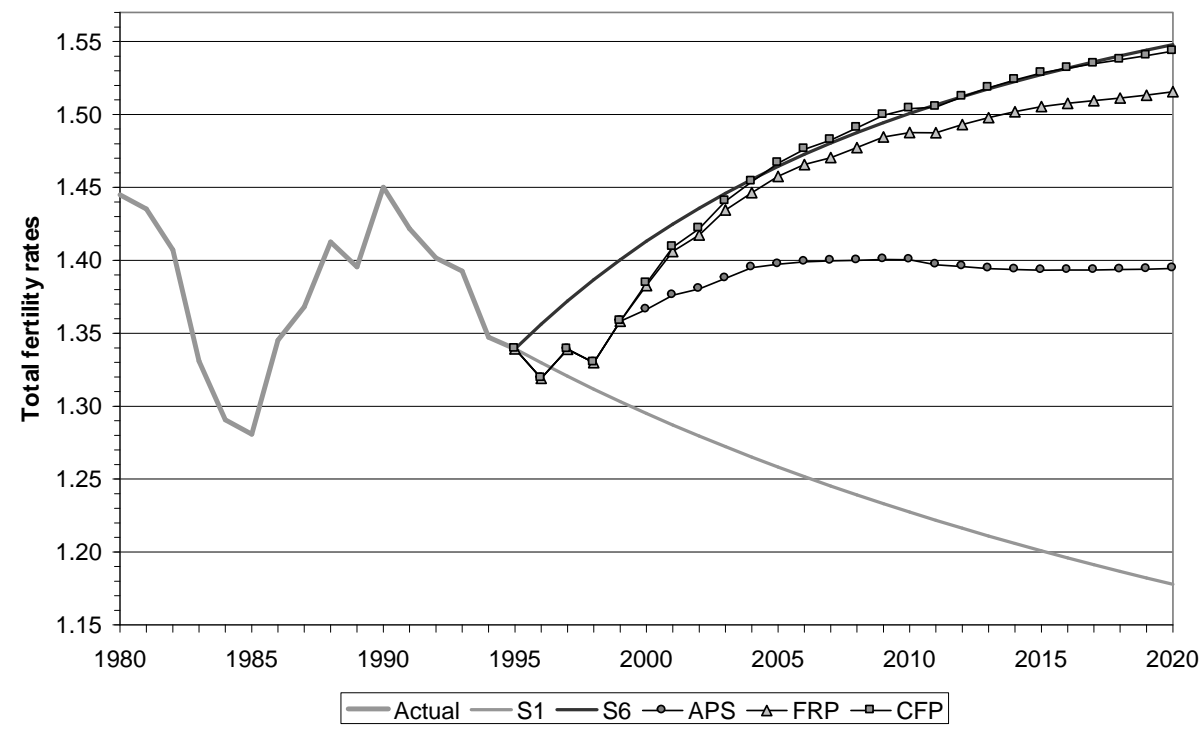

Figure 1. TFR in West Germany. Source: Cigno and Werding (2007) 
FRP. Pension coverage falls faster than in S6. This is achieved by making it more difficult to retire before the statutory age, ${ }^{26}$ and by indexing pension benefits to consumer prices instead of wages minus pension contributions as is current practice. ${ }^{27}$ The implicit pension subsidy is held constant and the child benefit rate increases by $1.2 \%$ a year as in S6. The clause, actually abolished in 1996, that a parent should withdraw from the labour market in order to qualify for Kindererziehungszeiten is reintroduced, and the maximum number of years for which the parent can be credited with this notional pension contribution is increased from 3 to 18.

CFP. Contributions-related pension benefits are reduced as in FRP. Pension benefits paid under the Kindererziehungszeiten scheme are related to the earning capacity of the pensioner's own children, rather than to the average earnings of the pensioner's contemporaries as was actually the case between 1986 and 1996. All other fertility-related subsidies are fixed at their 1995 level in real terms. The deficit of the pension fund current account is transformed from a collective subsidy for all current pensioners into an individual subsidy available only for pensioners with children. The individual pension subsidy is thus conditional on having children, but the per-child rate is the same for all pensioners with children.

S1 is essentially the status quo, and would have resulted in a continuation of the downward fertility trend experienced in the previous two and a half decades leading up to 1995. S6 represents a radical (and, probably, politically unrealistic) reversal of previous policies. This would bring the TFR back up to its 1972 level of 1.6 children per woman by the year 2020, a quarter of a child more than in 1995. In 25 years, German fertility would thus recover most of the ground that it had lost between 1960 ad 1995. That loss, it must be remembered, was a major cause of the financial crisis in the German pension system. The third scenario, APS, less radical than S6, reflects the pension reforms which were actually implemented between 1996 and 2001, and will be implemented in the future if the 2001 legislative framework is not further modified. Like S6, however, this policy scenario envisages very substantial increases in real child benefits (not contemplated in the 2001 legislation). Even with these enhanced fertility subsidies, the fertility recovery brought about by the 2001 reform would be more modest than that brought about by S6. The fourth scenario, FRP, involves toughening the 2001 legislative framework, and re-introducig the incentive for parents to withdraw from the labour market to raise children. This would lead to a more robust recovery than APS, but still a less robust one than S6. CFP, finally, is as close as one can get, using the

\footnotetext{
${ }^{26}$ As a result, the average age of retirement rises to 65 by the year 2010 .

${ }^{27}$ This indexation method, introduced in Germany in the year 2000 and later abandoned, is less favourable than the one actually in force because it does not take account of real wage growth.
} 
information provided by the econometric model in Cigno et al. (2003a), to the reform proposal outlined at the start of the present section. In this scenario, fertility would have recovered faster than in FRP, and caught-up with S6 by about 2005.

Subject to all kinds of caveat, these simulations seem to show that the same long-term fertility results could be obtained by either drastically cutting back pension coverage, and greatly increasing fertility subsidies, or reforming the pension system in the way we propose. But the two recepies would have very different effects on productivity growth, because the increase in the fertility subsidy envisaged by the first one would induce parents to substitute quantity for quality of children, and thus to invest less time and money in each child. Furthermore, the income-tax rise required to finance this increase in the subsidy would discourage labour. To some an extent, the income-tax increase would be compensated by the reduction in the pension contribution rate. If the pension system is Bismarckian like the German one, however, the aggregate labour distortion caused by pension contributions is likely to be small, and cutting contribution rates could even reduce aggregate labour supply (see Section 2). By contrast, the second recepy would actually reduce the labour distortion, because the income-tax rate would not need to increase, and pension contributions would be paid only when the agent is not engaged in raising children. When engaged in raising children, the agent would pay no contributions into scheme (i), and earn pension entitlements through scheme (ii), which does not distort the quantity/quality mix.

The full implementation of our reform proposal would generate a further efficiency gain as it would allow couples and individuals to specialize according to their personal comparative advantages in either income or child raising activities. This does not show in the Cigno-Werding simulations because the underlying econometric model predicts, in effect, the behaviour of the representative agent. Other things being equal, productivity may thus be expected to grow faster under our proposal, than if the government were to cut pensions and raise child benefits (or maintain existing policies), but there is no way of saying how faster because the model is silent on the matter, and the few available estimates of the growth effect of pension policy reported in Section 3 (Ehrlich and Zhong, 1998; Zhang and Zhang, 2004) refer to conventional pension systems, not to the unconventional one proposed here.

A final word about the political feasibility of pension reform. The reform proposed in the present paper would generate a Pareto improvement over the status quo. Couples and individuals with children would in fact benefit from the introduction of scheme (ii). Those who either cannot or choose not to have children would not lose, because scheme (i) would still allow them to qualify for a pension by working and paying contributions as at present. They would actually gain if the fertility and labour productivity increases generated by (ii) made it unnecessary for the government 
to raise contributions or cut benefits from their present level. By contrast, reducing the implicit return to participating in the existing pension scheme would reduce its political acceptability, and reducing the system to a mere safety net (as for example in the UK) would limit the government's ability to redistribute from the rich to the poor. Properly explained, ${ }^{28}$ the policy reform proposed here should thus be easier to sell to the electorate than the alternatives currently under discussion.

\section{REFERENCES}

Becker, G. S. and R. J. Barro (1988), “A reformulation of the economic theory of fertility”, Quarterly Journal of Economics 103, 1-25.

Breyer, F. (1989), “On the intergenerational Pareto efficiency of pay-as-you-go financed pension systems”, Journal of Institutional and and Theoretical Economics 145, 643-658.

Cigno, A. (1986), "Fertility and the tax-benefit system: a reconsideration of the theory of family taxation", Economic Journal 96, 1035-1051.

259-283.

(2006a), “A constitutional theory of the family”, Journal of Population Economics 19,

(2006b), “The political economy of intergenerational cooperation”, in S. C. Kolm and J. M. Ythier (eds.), Handbook of the Economics of Giving, Altruism and Reciprocity, Vol. 2. Amsterdam: North-Holland.

(2008), “Is there a social security tax wedge?”, Labour Economics 15, 68-77.

, L. Casolaro and F. C. Rosati (2003a), “The impact of social security on saving and fertility in Germany”, FinanzArchiv 59, 189-211.

, G. C. Giannelli, F. C. Rosati and D. Vuri (2006), "Is there such a thing as a family constitution? A test based on credit rationing", Review of Economics of the Household 4, 183-204.

, A. Luporini and A. Pettini (2003b), “Transfers to families with children as a principalagent problem”, Journal of Public Economics 87, 1165-1172.

A. Luporini and A. Pettini (2004), "Hidden information problems in the design of family allowances”, Journal of Population Economics 17, 645-655.

and F. C. Rosati (1992), "The effects of financial markets and social security on saving and fertility behaviour in Italy", Journal of Population Economics 5, 319-341.

and F. C. Rosati (1996), "Jointly determined saving and fertility behaviour: Theory, and estimates from Germany, Italy, UK, and USA", European Economic Review 40, 1561-1589.

\footnotetext{
${ }^{28}$ What needs to be explained, in particular, is that scheme (ii) is as much of a compromise between incentive and insurance considerations as scheme (i), and that there is nothing in our proposal to stop a person opting for the latter if her personal assessment of her own comparative advantages, and of the relative risk of investing in children vs. investing in her own career, makes her so inclined.
} 
and M. Werding (2007), Children and Pensions. Cambridge (Mass.): MIT Press.

Diamond, P. A. and P. R. Orszag (2005), “Saving Social Security”, Journal of Economic Perspectives 19, 11-32.

Disney, R. (2004), Are contributions to public pension programmes a tax on employment?, Economic Policy, July 2004, 269-311.

Ehrlich, I. and J.-G. Zhong (1998), "Social security and the real economy: An inquiry into some neglected issues”, American Economic Review (AEA Papers and Proceedings) 88, 151-157.

Entwisle , B. and C. R. Winegarden (1984), "Fertility and pension programs in LDCs: A model of mutual reinforcement”, Economic Development and Cultural Change 32, 331-354.

Fenge, R. (1995), "Pareto-efficiency of the pay-as-you-go pension system with intergenerational fairness”, Finanzarchiv 52, 357-364.

38, 38-48.

and V. Meier (2005), "Pensions and fertility incentives”, Canadian Journal of Economics

Hohm, C. H. (1975), “Social security and fertility: An international perspective”, Demography 12, 629-644.

Kotlikoff, J. and S. Burns (2004), The Coming Generational Storm: What You Need to Know about America's Economic Future. Cambridge MA: MIT Press.

Mitchell, B. (2003), International Historical Statistics: Europe 1750-2000. New York: Palgrave.

Nugent, J. B. and R. T. Gillaspy (1983), “Old-age pensions and fertility in rural areas of less developed countries”, Economic Development and Cultural Change 31, 809-829.

Puhakka, M. and M. Viren (2006), "Is the fertility decline a consequence of the growth of the welfare state? Evidence from historical data”, European Papers on the New Welfare 6, 46-52.

Schultz, T. P. (2007), “Population policies, fertility, women’s human capital, and child quality”, IZA DP 2815.

Sinn, H. W. (1990), "Korreferat zum Referat von K. Jaeger“, in B. Gahlen, H. Hesse and H. J. Ramser (eds.), Theorie und Politik der Sozialversicherung. Tübingen: Mohr-Siebeck.

------------- (2000), "Why a funded pension system is useful and why it is not useful”, International Tax and Public Finance 7, 389-410.

Werding, M. and H. Hofmann (2005), “Die fiskalische Bilanz eines Kindes im deutschen Steuerund Sozialsystem“, Ifo Forschungsbericht, No. 27.

Zhang, J. and J. Zhang. (2004), "How does social security affect economic growth? Evidence from cross-coutry data”, Journal of Population Economics 17, 473-500. 


\section{Policy summary}

Conventional pension systems suffer from a design defect which makes them financially unsustainable, and a source of inefficiency for the economy as a whole. The paper outlines a second-best policy which includes a public pension system made up of two parallel schemes, (i) a Bismarckian one allowing individuals to qualify for a pension by working and paying contributions in the usual way, and (ii) an unconventional one allowing them to qualify for a pension by having children, and investing time and money in their upbringing. In (i), individual benefits increase with individual earnings and contributions. In (ii), they increase with the earnings potential of the pensioner's own children, estimated on the basis of observable parameters, such as education achievement, and actual labour market performance, up to the time when the parent retires. The benefit formulae should be designed to partially compensate the pensioner if his own lifetime earnings turn out to have been unsatisfactory in scheme (i), or if his children's estimated earnings capacity turns out to be unsatisfactory in scheme (ii). Individuals should be free to switch in and out of the two schemes as and when they like. Those who, by chance or choice, remain childless would stay in scheme (i) throughout their working lives. This freedom of choice would encourage couples and individuals to specialize in either child-raising or money-raising activities according to their personal comparative advantages (the government would not need to know these comparative advantages, it is sufficient that individuals do). It would also minimize labour distortion, because (ii) does not tax labour, and (i) taxes or subsidizes it only for the amount of time that a person allocates to this scheme.

A small element of what is being proposed exists already in some pension systems, but it rewards fertility, not investment in the children's human capital. The majoration de durée d'assurance pour enfants in the French Régime Général, and the Swedish extrapension för barn, are pension-based fertility subsidies. Something resembling (ii) was introduced in Germany in 1986, when the government started crediting parents who withdrew from the labour market to look after a child with a notional pension contribution, Kindererziehungszeiten. As this reflected, however imperfectly, the opportunity-cost component of the cost of having a child, the policy went some way towards providing an incentive not just to have children, but also to spend time with them. Since 1996, however, the condition that the parent should actually give up work in order to qualify for the benefit has been removed, and Kindererziehungszeiten has become a pension-based fertility subsidy just like the French and Swedish ones. 
Numerical simulations reported in the paper show that the same long-term fertility results could be obtained by either drastically cutting back pension coverage, and greatly increasing fertility subsidies, or reforming the pension system in the way we propose. But the two recepies would have very different effects on productivity growth, because the increase in the fertility subsidy envisaged by the first one would induce parents to have more children, and invest less time and money in each child. Furthermore, the income-tax rise required to finance this increase in the subsidy would discourage labour. By contrast, the second recepy would actually reduce the labour distortion, because the income-tax rate would not need to increase, and pension contributions would be paid only when the agent is not engaged in raising children. The full implementation of our reform proposal would generate a further efficiency gain as it would allow couples and individuals to specialize according to their personal comparative advantages in either income or child raising activities. Properly explained, the proposed reform should thus be easier to sell to the electorate than the alternatives (reducing benefits one way or another) currently under discussion. What needs to be explained, in particular, is that scheme (ii) is as much of a compromise between incentive and insurance considerations as scheme (i), and that there is nothing in our proposal to stop a person opting for the latter if her personal assessment of her own comparative advantages, and of the relative risk of investing in children vs. investing in her own career, makes her so inclined. 